\title{
Work conducted in preparation for partial extraction of X41 shaft pillar at Mount Isa Mines
}

\author{
GS Potgieter Glencore Mount Isa Mines, Australia
}

\begin{abstract}
The X41 shaft at Mount Isa Mines is one of the two vertical shafts and one of the three main accesses used to transport men and material to the underground copper mine. The X41 shaft is located on the eastern edge of the orebody. The X41 shaft is intersected by a number of geological features, most notable of these are the W41 fault, the W42 fault and the basement contact zone. The extraction of the orebody has allowed the block formed by these structures to rotate. The rotation has resulted in deformation to the shaft barrel, which in turn has resulted in damage to the shaft lining and deformation to the shaft steelwork. This deformation was first identified in the early 1980s. Due to the deformation and associated damage, a shaft pillar was put in place to protect the shaft. As the mine approaches its end of life, the relative value of the ore contained within the shaft pillar has increased considerably. An investigation was undertaken to determine the probable impacts to shaft operations if ore within this shaft pillar were to be extracted.

This paper discusses the assessments that were undertaken to determine the extent and rates of deformation that are expected to occur due to the mining operations. It describes the instrumentation that is being used to verify these predictions. Finally, it discusses the operational controls required to safely extract portions of the shaft pillar while allowing it to maintain operations supplying workers and material to the underground mine.
\end{abstract}

\section{$1 \quad$ Context}

\subsection{Locality}

Mount Isa Copper Operations (MICO) is a large and integrated mining complex located in Mount Isa, Queensland, Australia (Figure 1). The underground mining operation comprises two copper mines, made up of a number of world-class copper orebodies that produce approximately 6.5 million tonnes of copper ore per annum.

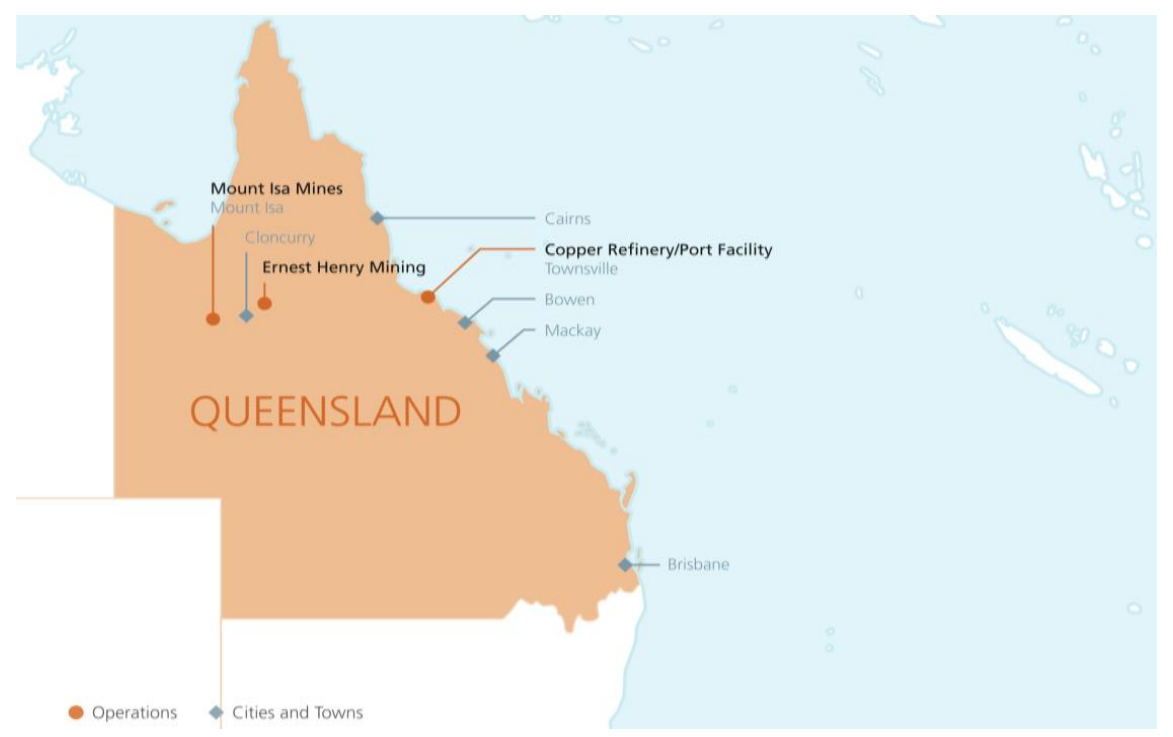

Figure 1 Locality 
Operations in MICO extend from 3,000 $\mathrm{n}$ in the south to 7,200 $\mathrm{n}$ in the north along strike and $1450 \mathrm{E}$ to $2500 \mathrm{E}$ normal to strike. Operations extend from surface to a depth of $1,850 \mathrm{~m}$.

The copper orebodies are accessed via two vertical shafts as well as a decline from surface. The X41 shaft services the southern portion (X41 mine) of the copper operations, whilst the R62 shaft services the northern deep portion (Enterprise mine) of the copper operation. The decline is used for the movement of large equipment as well as for egress. A further two vertical shafts are used for hoisting of ore. These are U62 and M62 shafts. M62 shaft is an internal shaft and hoists ore from the Enterprise mine. The ore from both Enterprise mine and X41 mine is hoisted up the U62 shaft to surface. The locations of the shafts are shown in Figure 2.

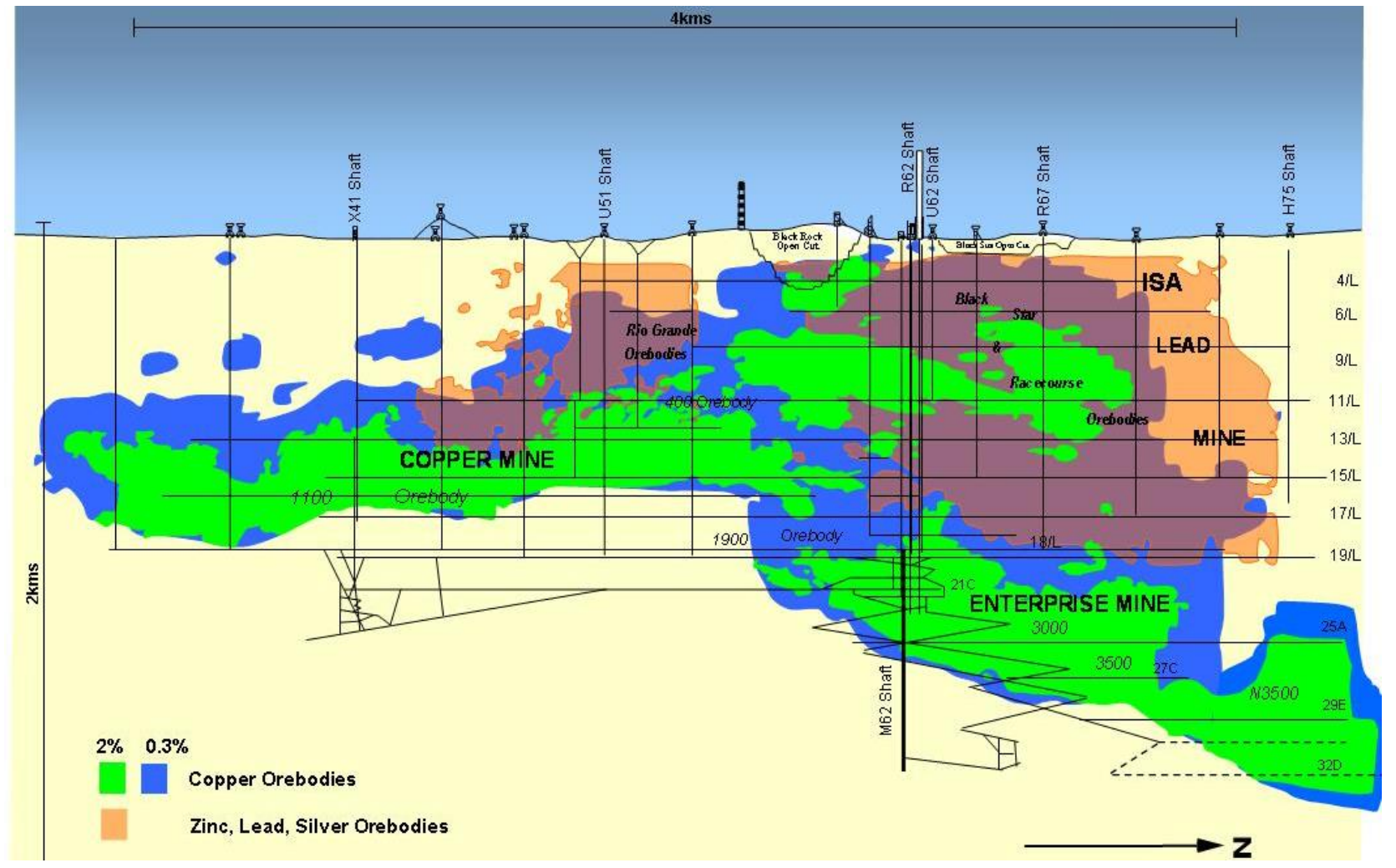

Figure 2 Long section - MICO

The sequence of stopes to be extracted is located to the east of the orebody as shown in Figure 3. The shaft is located to the east of the stopes, as shown in Figure 4.

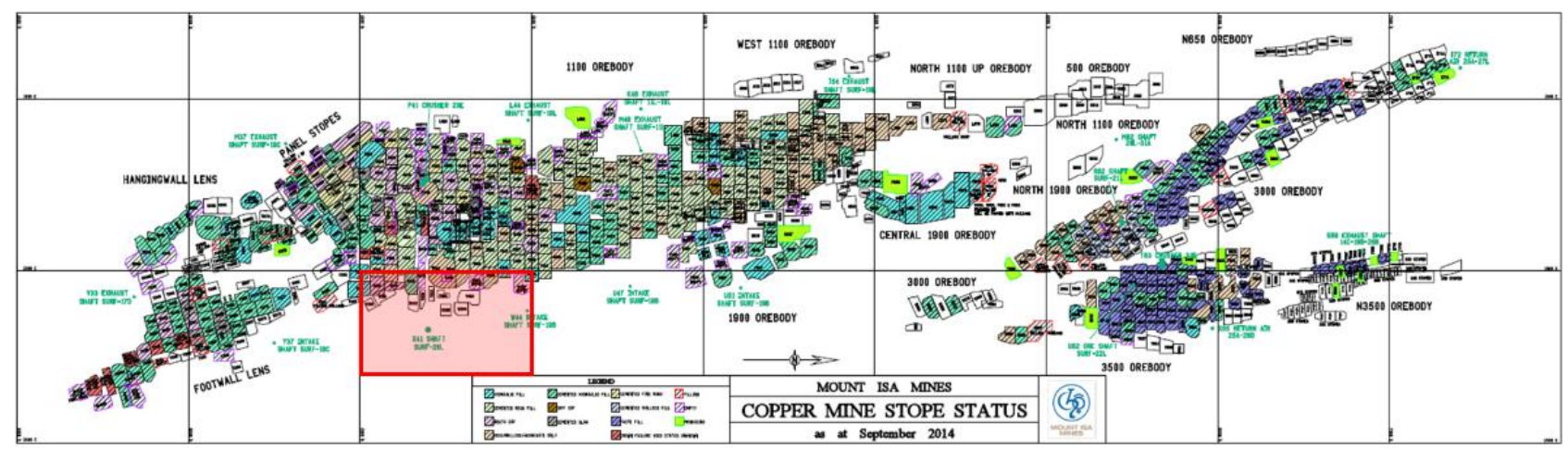

Figure 3 Location of stopes in relation to mine (plan view) 


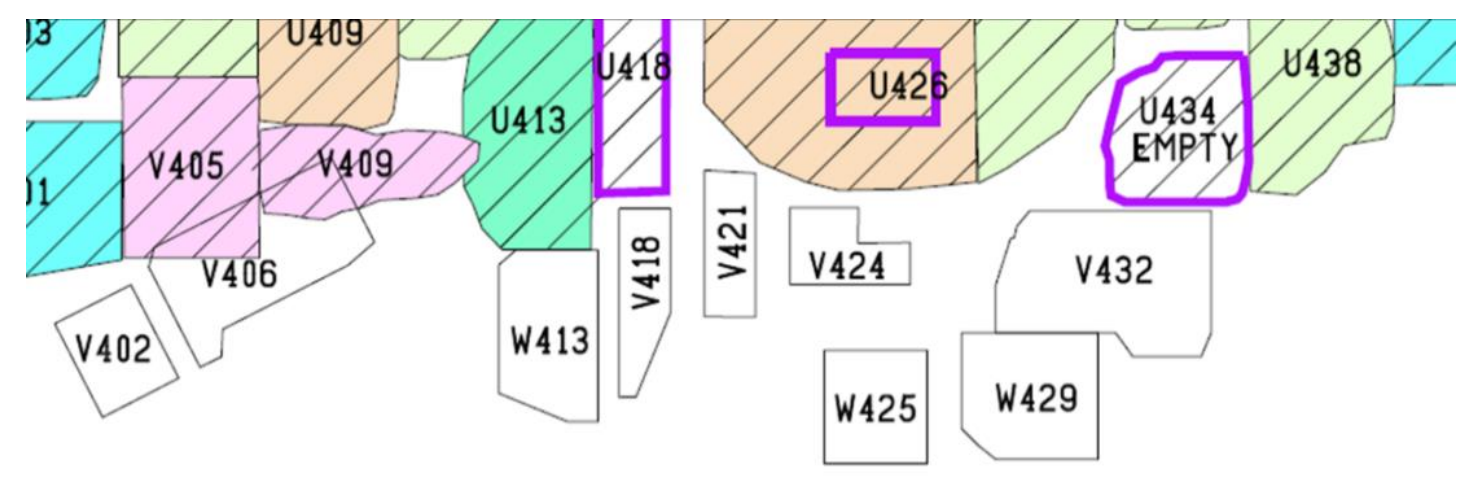

\section{X41 SHAFT \\ SURF-2OL}

Figure 4 Location of the shaft in relation to the stopes (plan view)

\subsection{Geology}

The X41 shaft is intersected by the W41 and W42 faults, which are believed to be causing the deformation and damage.

The W41 fault dips steeply between 75 and $85^{\circ}$ towards the northwest and strikes between 205 and $215^{\circ}$. The shear zone is between 5 to $20 \mathrm{~m}$ wide and has clay and carbonaceous rubble fill. The W41 fault intersects the shaft between 15 and 17 Levels.

The W42 fault dips steeply between 75 and $85^{\circ}$ towards the northwest and strikes between 20 and $45^{\circ}$. The shear zone is between 1 to $1.5 \mathrm{~m}$ in width and thins with depth. The W42 fault intersects the shaft at 11 Level.

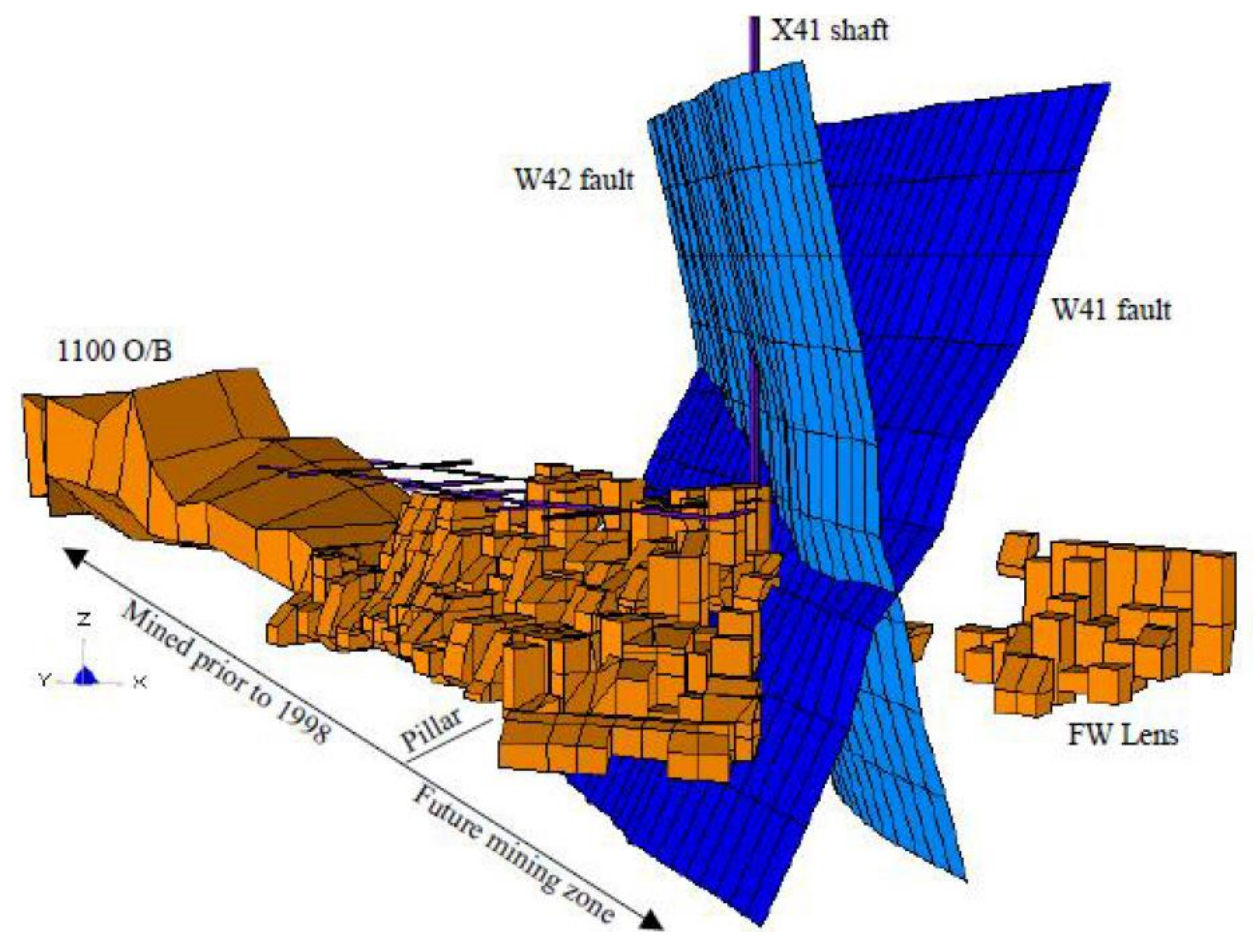

Figure 5 W41 and W42 fault intersections (looking from southwest) after Bruneau (2000) 


\subsection{Infrastructure}

The X41 shaft contains a single cage, counterweight and escape ladder way. The majority of the services are located on the southern wall as per Figure 6.

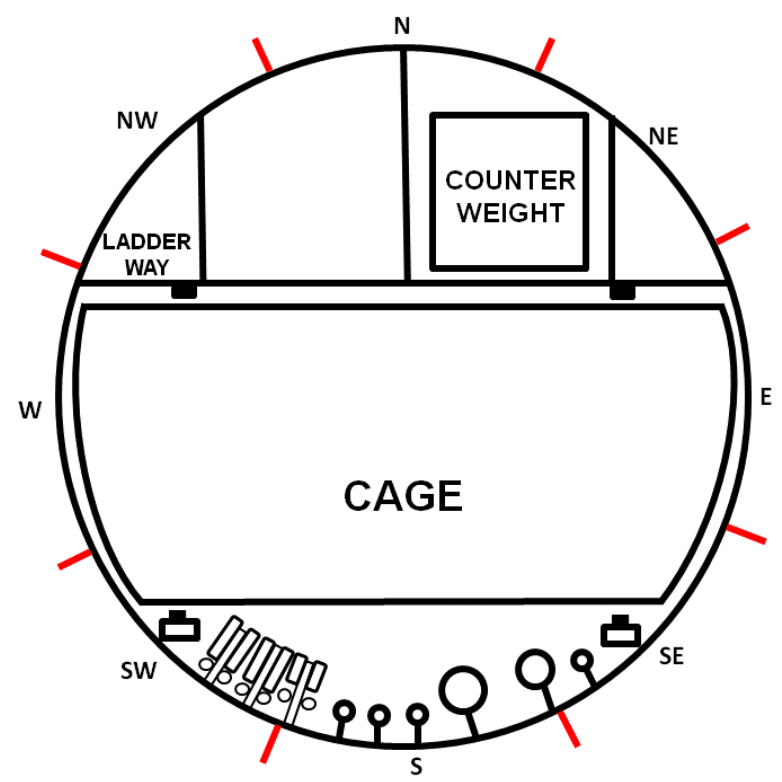

Figure 6 X41 shaft infrastructure

\section{$2 \quad$ Historic rock mechanics investigations}

A large number of investigations have been conducted into the stability of X41 shaft over the last 20 years. Included below is a summary a few of the key investigations.

Bruneau (2000) submitted her thesis detailing the damage observed in the X41 shaft. She describes deformation having been observed in the 1980s and then again in the 1990s. Although Bruneau (2000) references the work of a number of individuals, her work is the first that the author was able to locate, that fully describes the damage and details the mechanism responsible for the damage to the shaft lining and steelwork. Bruneau (2000) is also the first person to begin a systematic campaign to gather data relating to fault displacement along with damage mapping within the shaft. Bruneau (2000) describes displacements along the W41 fault and W42 fault and postulates that the mobilisation of the block formed by the W41, W42 and possibly the basement contact zone (BCZ) into the mining void is responsible for the damage.

Bruneau et al. (2003a; 2003b) published two papers relating to X41 shaft. The first paper gives a detailed description of the instrumentation installed in the shaft as well as a comprehensive history of measured deformations and the mining activities that were associated with increased rates of deformation. The instrumentation, although crude by today's standards, provided a wealth of data from 1995 to 1998. Bruneau et al. (2003a) shows that although displacements on the W41 fault and W42 fault show strong correlation to the damage observed in the shaft, the BCZ does not have the same strong correlation. The second paper sets out to increase the understanding of the influence of the faults on the integrity of the shaft and to quantify the relative rate of displacement with respect to a modelling sequence. This second paper describes the use of Map3D to obtain the required results. Bruneau et al. (2003b) discusses how although they could not obtain absolute figures with a great deal of confidence, relative figures were obtainable and could be used for the basis of mine design.

Sloane drafted two internal memorandums. The first memorandum (2005a) detailed the state of the instrumentation in and around the X41 shaft. The second memorandum (2005b) made recommendations as to the instrumentation that would be required to effectively monitor shaft deformations that were expected to occur as a result of future mining. 
At that time a single bar extensometer remained in working order and most systematic monitoring had stopped in or around 2000. Most of the instrumentation recommended by Sloane (2005b) was not installed, as mining was not occurring in the vicinity. Regular visual inspections of the X41 shaft continued to take place. Telltale slides were installed on cracks in the lining, refer to Figure 7, changes in the cracks were recorded from month to month; however, due to the fragility of the slides and the nature of the inspections, this data is not a reliable measure of deformation. A series of off-shaft bar extensometers similar to the one shown in Figure 8 were installed. This was due to the relatively low cost and effort when compared to installing instrumentation within an operational shaft.

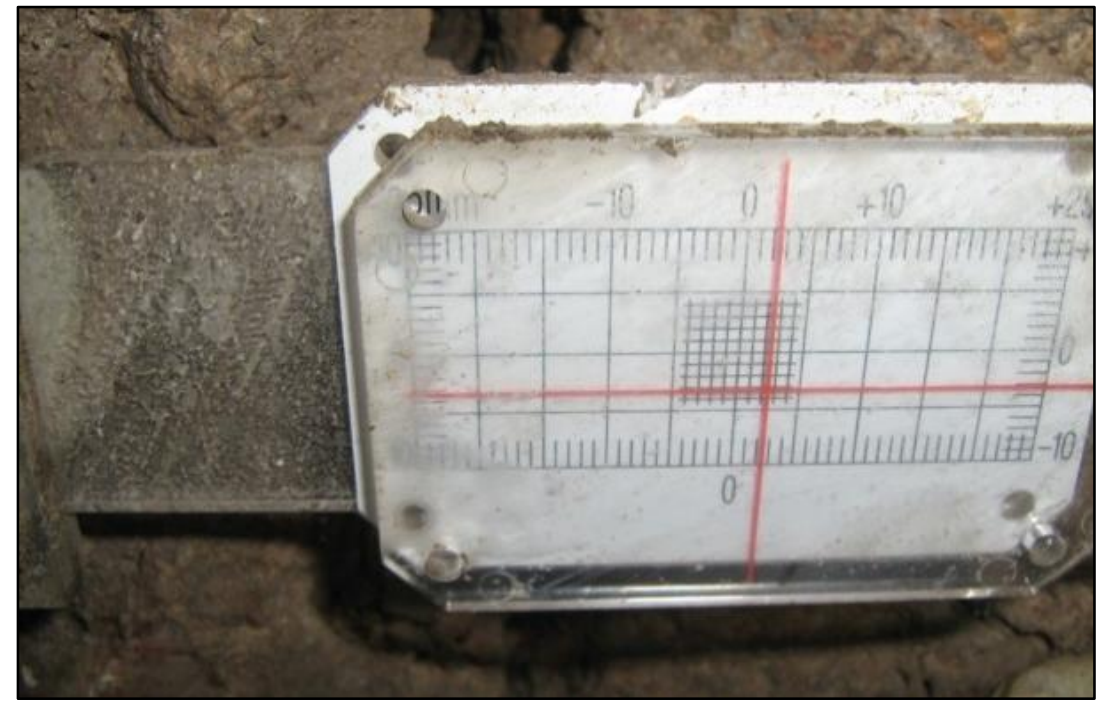

\section{Figure 7 Avongard telltale}

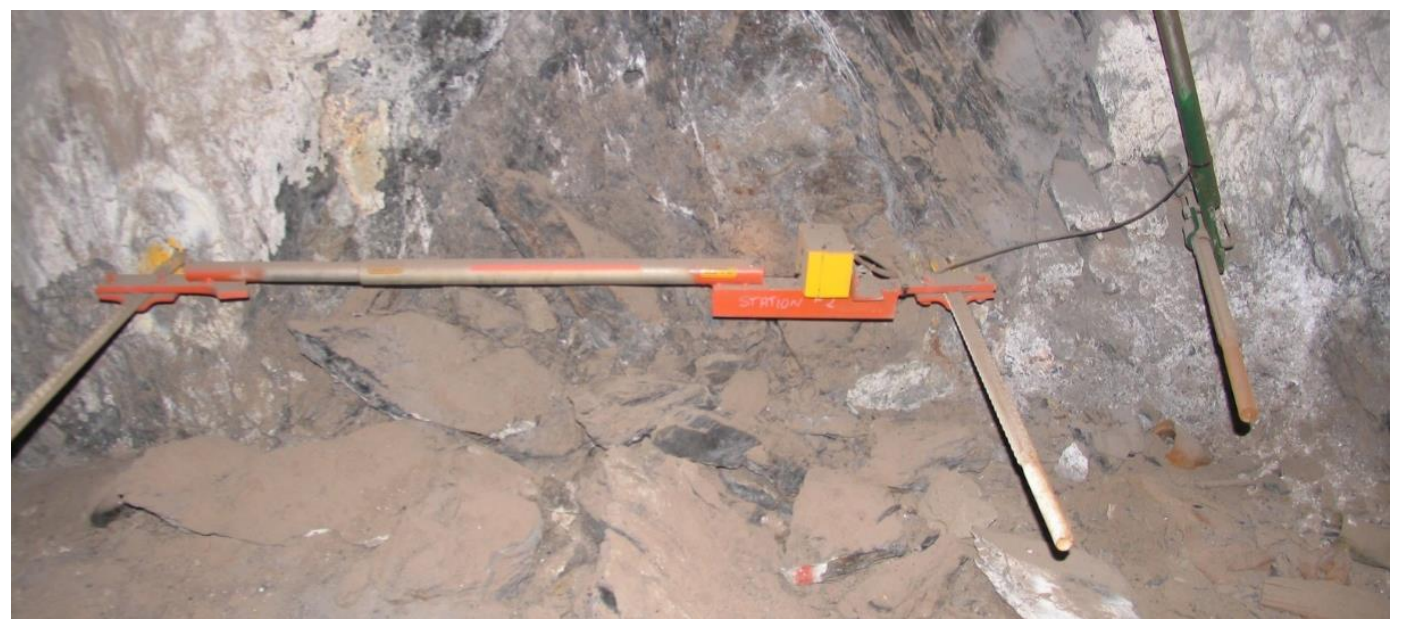

Figure 8 Bar extensometer

Doolan (2013), on behalf of Mining One Consultants, was commissioned to review the shaft pillar surrounding the X41 shaft with a view to extracting the stopes adjacent to the X41 shaft. As a result of the investigation, Doolan (2013) compiled a detailed history of instrumentation, modelling, monitoring, deformations and inspections. Doolan (2013) also produced a damage map of the shaft showing the damage that had occurred due to deformations to that point (Figure 9). 


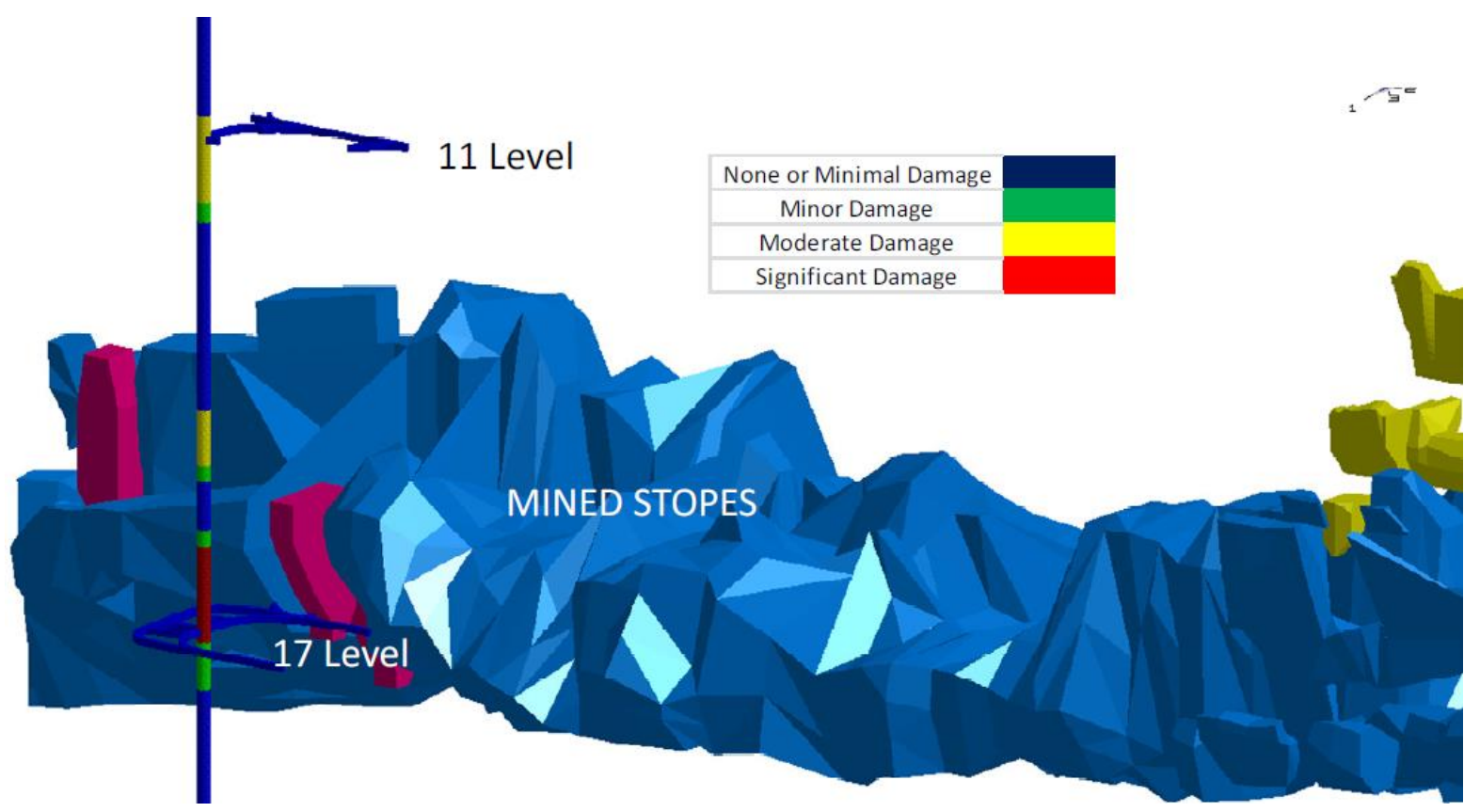

Figure 9 Damage mapping in X41 shaft

The scope did not include the need to obtain absolute values for deformations and deformation rates. The relative rates of deformation for each step of the mining sequence and the point at which these rates would exceed the rates experienced in the past were required. The model was calibrated against past models, historic mining and deformation data and shaft inspection reports. Based on this modelling, as well as consideration to operational constraints, an extraction sequence was selected (Figure 10).
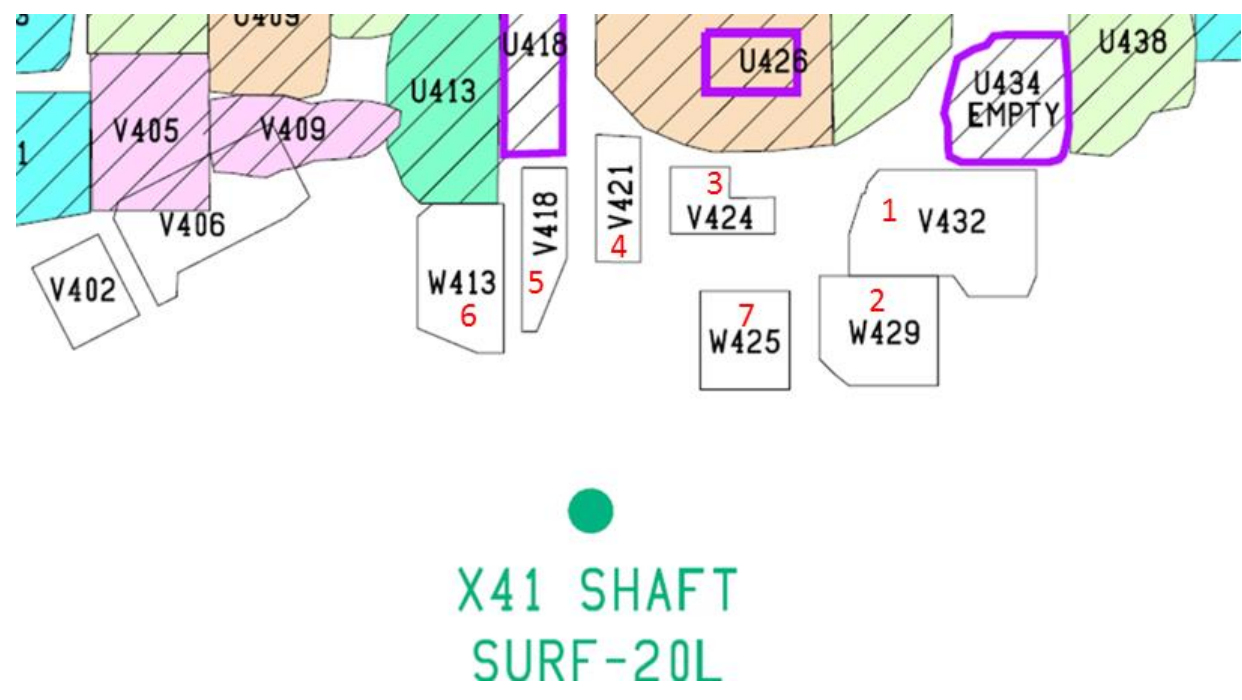

Figure 10 Extraction sequence

Modelling indicated that the extraction of the second stope in the sequence would have a moderate effect on the shaft and that the extraction of the seventh would have a significant effect. The extraction of the remaining five stopes would have minimal impact on the shaft. Extraction of stopes V402 and V406 would also have minimal and moderate effects respectively; however, they are not sequence constrained as are the first seven stopes and may be mined 'out of sequence'.

Doolan's (2013) report made recommendations as to the requirement for instrumentation to monitor the extraction of the stopes in the sequence. The recommendation included the need for in-shaft instruments, off-shaft instruments (to measure deformation on the W41 and W42 faults), as well as blast vibration monitoring. 


\section{Contained copper}

The potential for damage to critical infrastructure whilst mining within close proximity to an operating shaft is significant. Rehabilitation will be costly. Operational delays could be large and the controls required to ensure safe extraction will be expensive. The mining sequence includes approximately $800,000 \mathrm{t}$ of ore and approximately $19,000 \mathrm{t}$ of copper. This is sufficient to offset the associated risk and cost. The projected revenue exceeds the costs of mining, monitoring, shaft maintenance, shaft rehabilitation and associated remedial works.

\section{$4 \quad$ Risks}

Along with the financial benefits of extracting this stope sequence, a number of risks and controls have been identified (Table 1).

Table 1 Risks and controls

\begin{tabular}{|c|c|c|}
\hline Risk type & Risk & Control \\
\hline $\begin{array}{l}\text { Health and } \\
\text { safety }\end{array}$ & $\begin{array}{l}\text { Cage travel is impeded resulting in } \\
\text { injury to personnel in the } \\
\text { conveyance }\end{array}$ & $\begin{array}{l}\text { Shaft monitoring instrumentation } \\
\text { Shaft inspections } \\
\text { Shafts maintenance schedule } \\
\text { Shaft taken out of service during stope firings }\end{array}$ \\
\hline $\begin{array}{l}\text { Health and } \\
\text { safety }\end{array}$ & $\begin{array}{l}\text { Shaft lining detaches and impacts } \\
\text { on personnel in or adjacent to the } \\
\text { X41 shaft }\end{array}$ & $\begin{array}{l}\text { Shaft monitoring instrumentation } \\
\text { Shaft Inspections } \\
\text { Shafts maintenance schedule } \\
\text { Shaft taken out of service during stope firings } \\
\text { Stope firings are modelled to minimise peak } \\
\text { particle velocities (PPVs) }\end{array}$ \\
\hline Business & $\begin{array}{l}\text { Cage travel is impeded resulting in } \\
\text { damage to shaft infrastructure }\end{array}$ & $\begin{array}{l}\text { Shaft monitoring instrumentation } \\
\text { Shaft Inspections } \\
\text { Shafts maintenance Schedule } \\
\text { Shaft taken out of service during stope firings }\end{array}$ \\
\hline Business & $\begin{array}{l}\text { Shaft lining detaches and falls } \\
\text { down shaft resulting in damage to } \\
\text { shaft infrastructure }\end{array}$ & $\begin{array}{l}\text { Shaft monitoring instrumentation } \\
\text { Shaft Inspections } \\
\text { Shafts maintenance schedule } \\
\text { Stope firings are modelled to minimise PPVs }\end{array}$ \\
\hline Business & $\begin{array}{l}\text { Stope sequence cannot be } \\
\text { extracted due to larger than } \\
\text { predicted deformations resulting in } \\
\text { a loss of revenue }\end{array}$ & $\begin{array}{l}\text { Shaft monitoring instrumentation } \\
\text { Shaft inspections } \\
\text { Shafts maintenance schedule } \\
\text { Shaft taken out of service during stope firings } \\
\text { Stope firings are modelled to minimise PPVs } \\
\text { Off-shaft instrumentation to calibrate models } \\
\text { Stope redesign and resequencing to minimise } \\
\text { negative impacts }\end{array}$ \\
\hline
\end{tabular}




\section{Controls}

\subsection{In-shaft instrumentation}

Hills (2014), on behalf of pitt\&sherry, was commissioned to draft a detailed monitoring plan for X41 shaft. The monitoring would provide early warning of excessive shaft deformation that could potentially affect the safe operation of the cage, and an increase in understanding of mining induced movement on the W41 and W42 faults in terms of their rates and orientation of creep.

Based on the recommendations by Hills (2014) and Doolan (2013) an extensive array of instruments has been installed in X41 shaft. This instrumentation feeds all of the data in real time to a server that is remotely accessible. Being able to remotely access the data in real time means that post firing inspections can be undertaken after checking the status of the instruments, allowing the personnel who will be conducting the inspection to have forewarning of any deterioration that may have occurred prior to the inspection taking place.

The Mine Design Technologies (MDT) system installed in the shaft was chosen partly for its ability to integrate with the seismic system.

Thirty-two tiltmeters have been installed on four horizons on the four vertical cage guides, two per location in a biaxial arrangement as per Figure 11, to measure deformation of the guides. Forty-eight strain gauge sensors have been installed in symmetrically mirrored clusters of four on twelve horizons to measure deformation of the shaft buntons as per Figure 12.

Thirty-six ground movement monitors (GMMs) have been installed at six locations in a radial pattern on six horizons to measure deformation of the concrete shaft lining. Figure 13 shows a unit prior to installation.

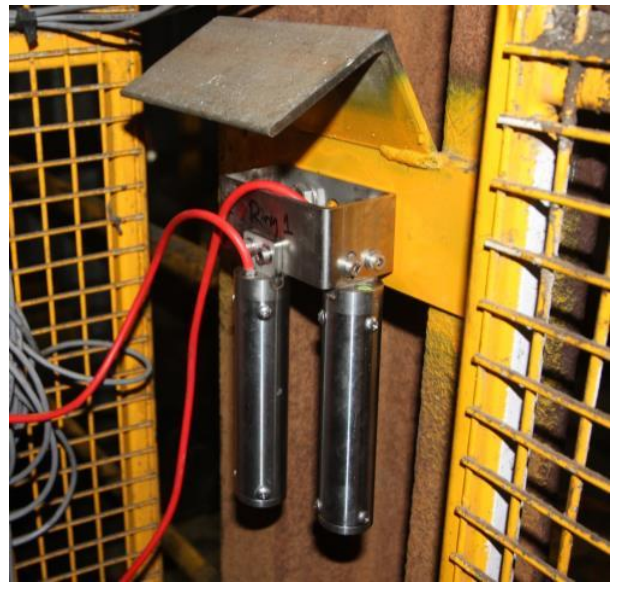

Figure 11 Tiltmetres

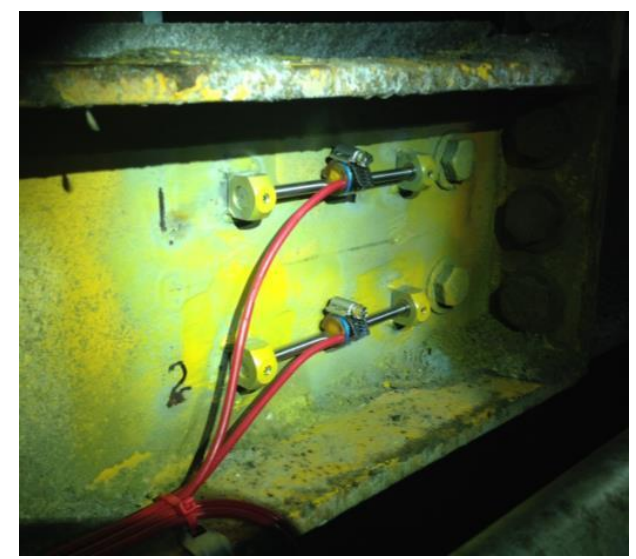

Figure 12 Strain gauges 


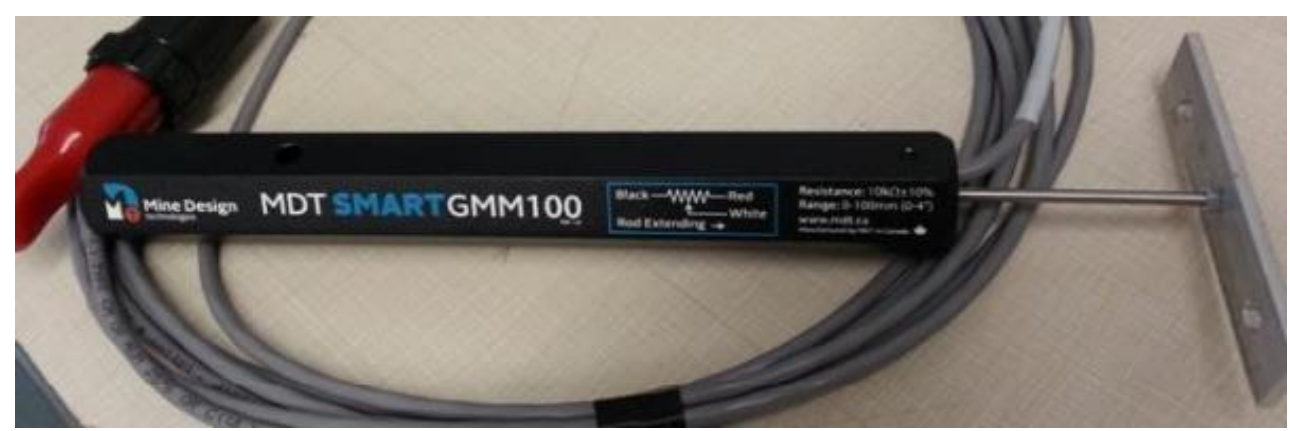

Figure 13 Ground movement monitor

A wireless network has been created in the shaft to relay data to $19 \mathrm{~B}$ sublevel underground where it is transmitted via the existing seismic monitoring network to R62 shaft and then up to surface. The creation of a wireless network in the shaft greatly reduced the number of physical connections and cable needed to implement the instrumentation. The installed network would require the equivalent of $14 \mathrm{~km}$ of Ethernet cable to transmit the data in a wired system. The in-shaft network consists of the instruments, which are connected to instrument specific junction boxes, and nodes at the cluster horizons. Whilst also collecting the data directly from instruments, the nodes act as wireless repeaters, allowing data to be compiled at the NetSP located on 19B, shown in Figures 14, 15 and 16.

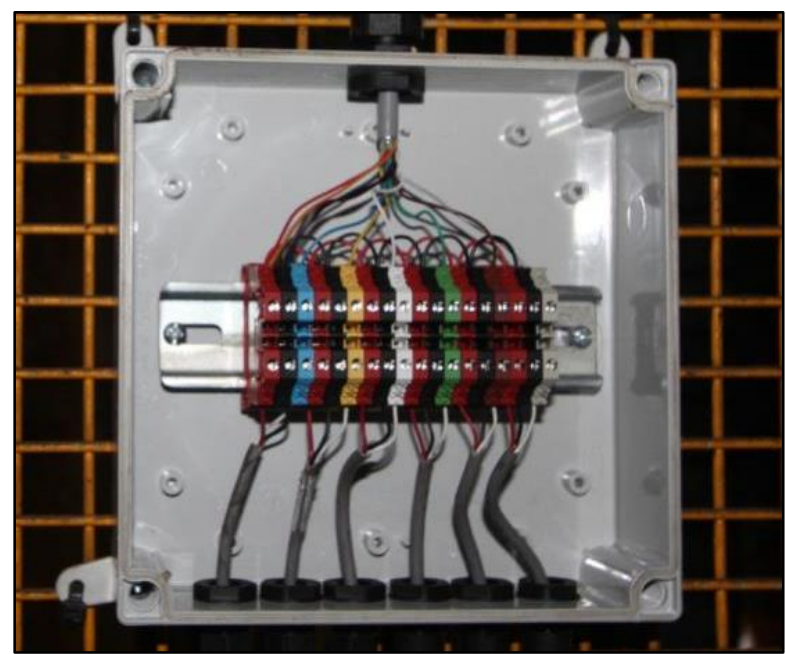

Figure 14 GMM junction box for extensometers

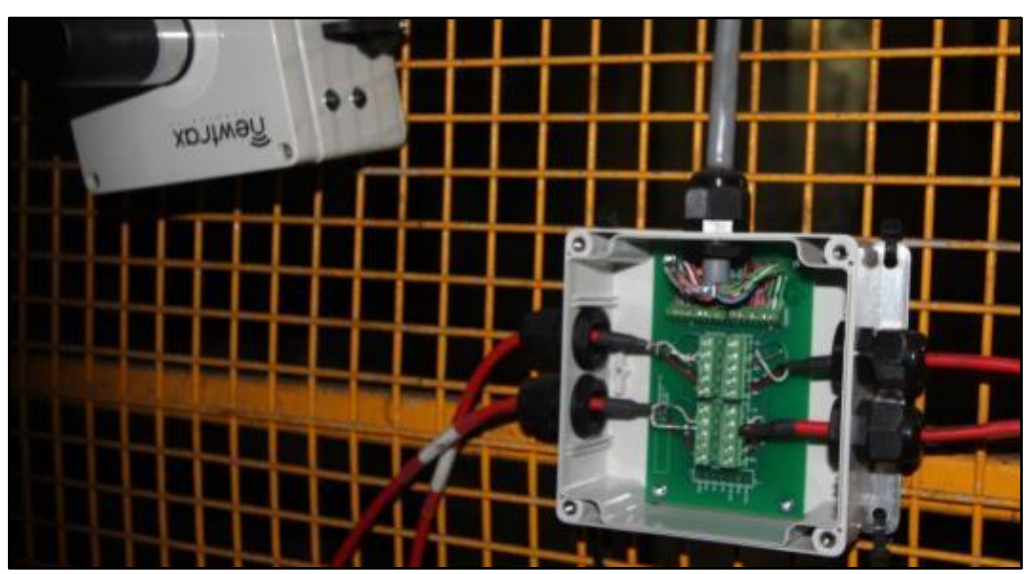

Figure 15 Vibrating wire junction box and transmission node 


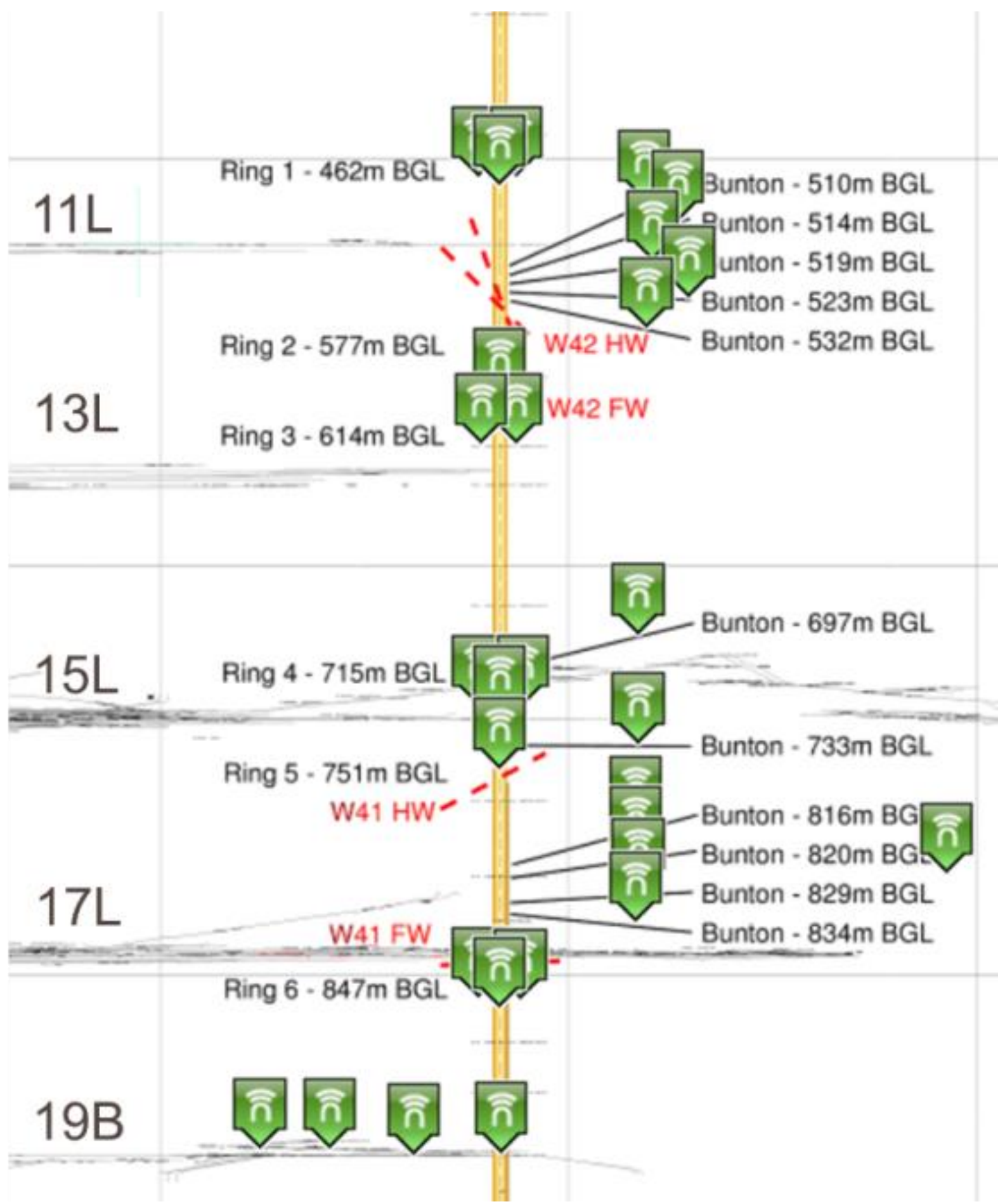

Figure 16 Diagram showing X41 wireless network

\subsection{Off-shaft instrumentation}

An off-shaft instrumentation program has also been initiated and at the time of writing. Six of the fifteen planned bar extensometers have been installed as per Figure 17. These extensometers will provide information on the deformation of the W41 fault, the W42 fault and BCZ. This information will be used to verify the current hypothesis as to shaft deterioration being due to mobilisation along these structures. They will also monitor the response of the faults to changes to the clamping forces on the faults as a result of mining. 


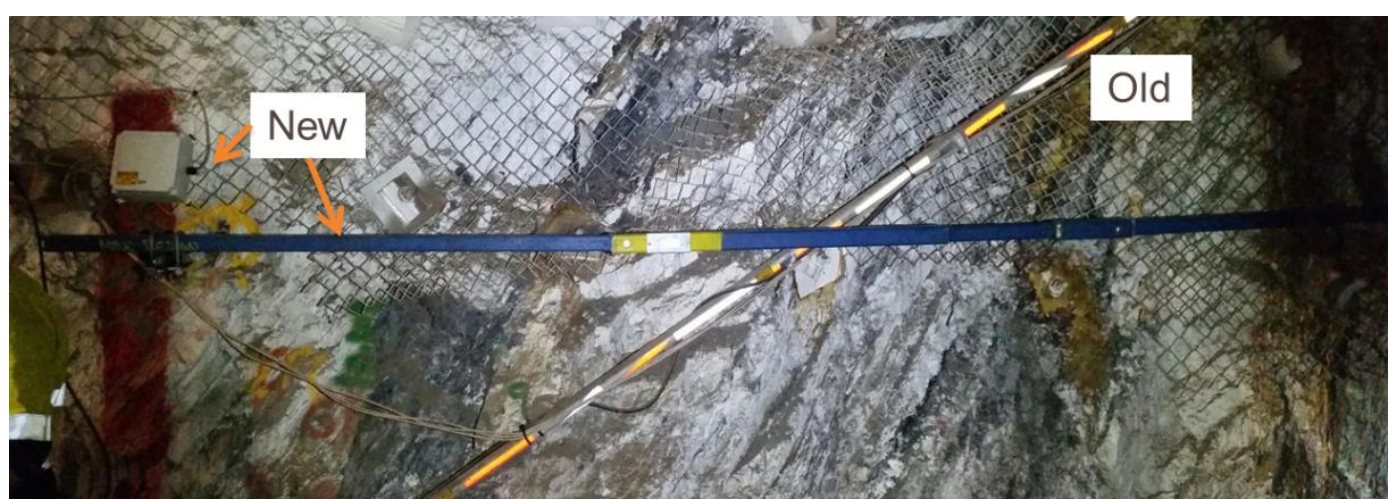

Figure 17 New and old bar extensometers

\subsection{Seismic monitoring}

A seismic monitoring network has long been in place for the Enterprise mine. The seismic system has been extended to include X41 shaft both to monitor the shaft during extraction and also to reflect the increased focus on mine wide seismic risk management. The extension consists of four uniaxial and two triaxial geophones and all of the associated communications equipment installed near X41 shaft on $19 \mathrm{~B}$ and $15 \mathrm{~L}$.

Accelerometers were considered as part of the expansion; however, geophones were selected following consultation with the Institute of Mine Seismology (IMS) as the geophones would be more useful as part of the larger seismic risk management plan.

The extension is via fibre-optic cable between the X41 and R62 shafts is shown in Figure 20.

While the primary objective of the seismic network remains the monitoring of seismic activity, the information obtained from the geophones enables the calculation of PPV at different locations in the shaft and detailed analysis of stope firings to verify firings have occurred as planned with no misfires or mistimed holes. The X41 seismic extension is shown in Figures 18, 19 and 20.

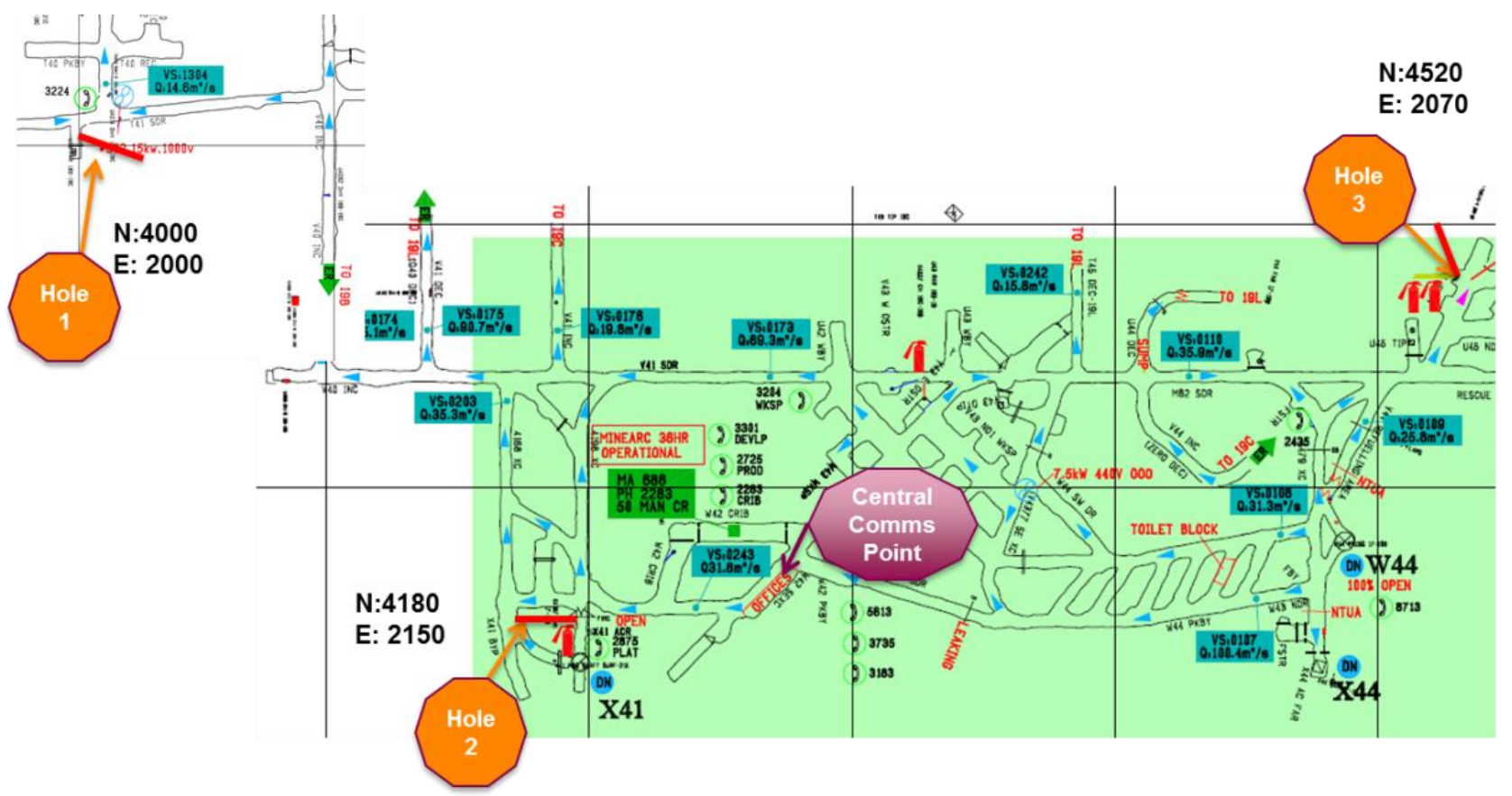

Figure 18 Seismic system layout on 19B 


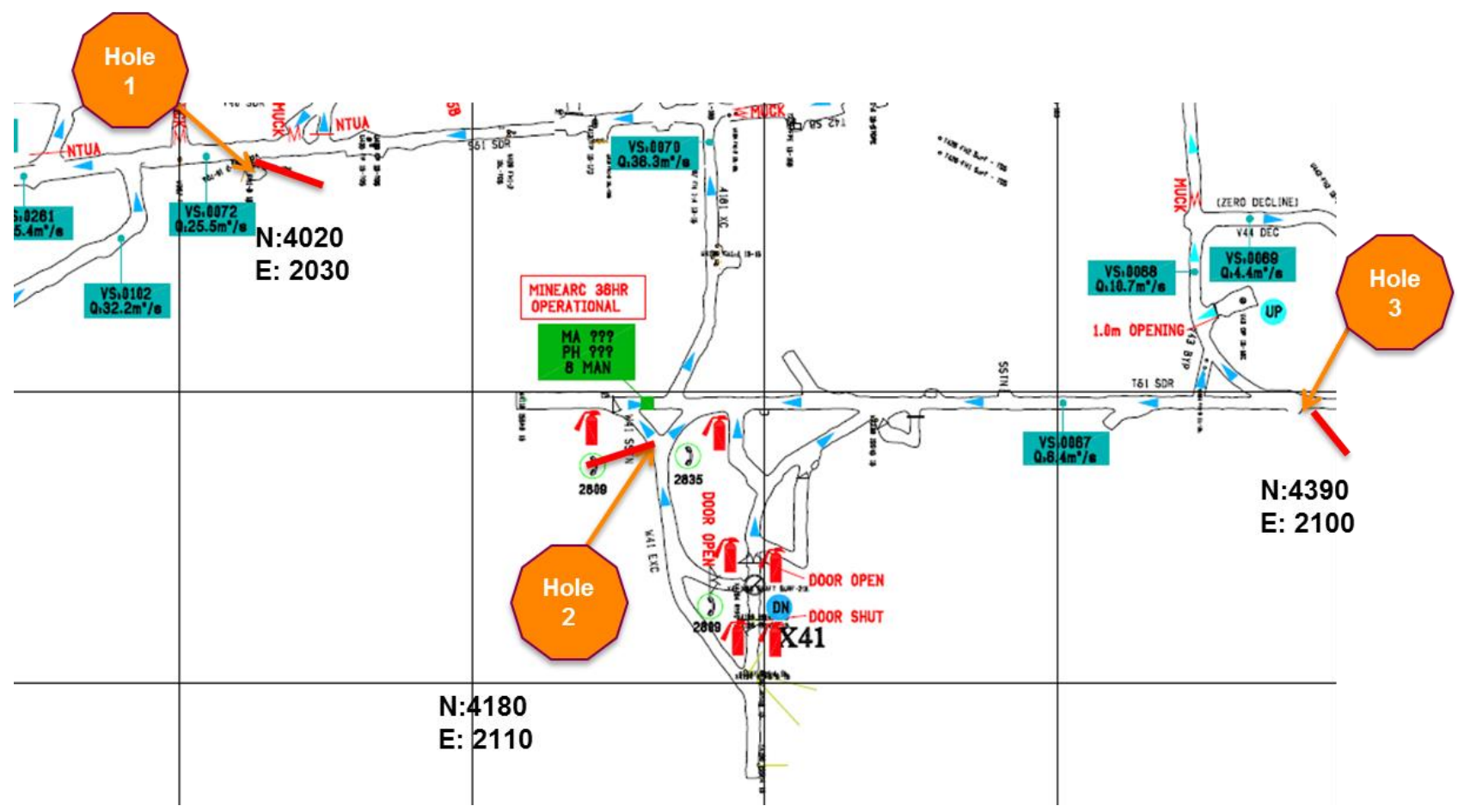

Figure 19 Seismic system layout on 15L

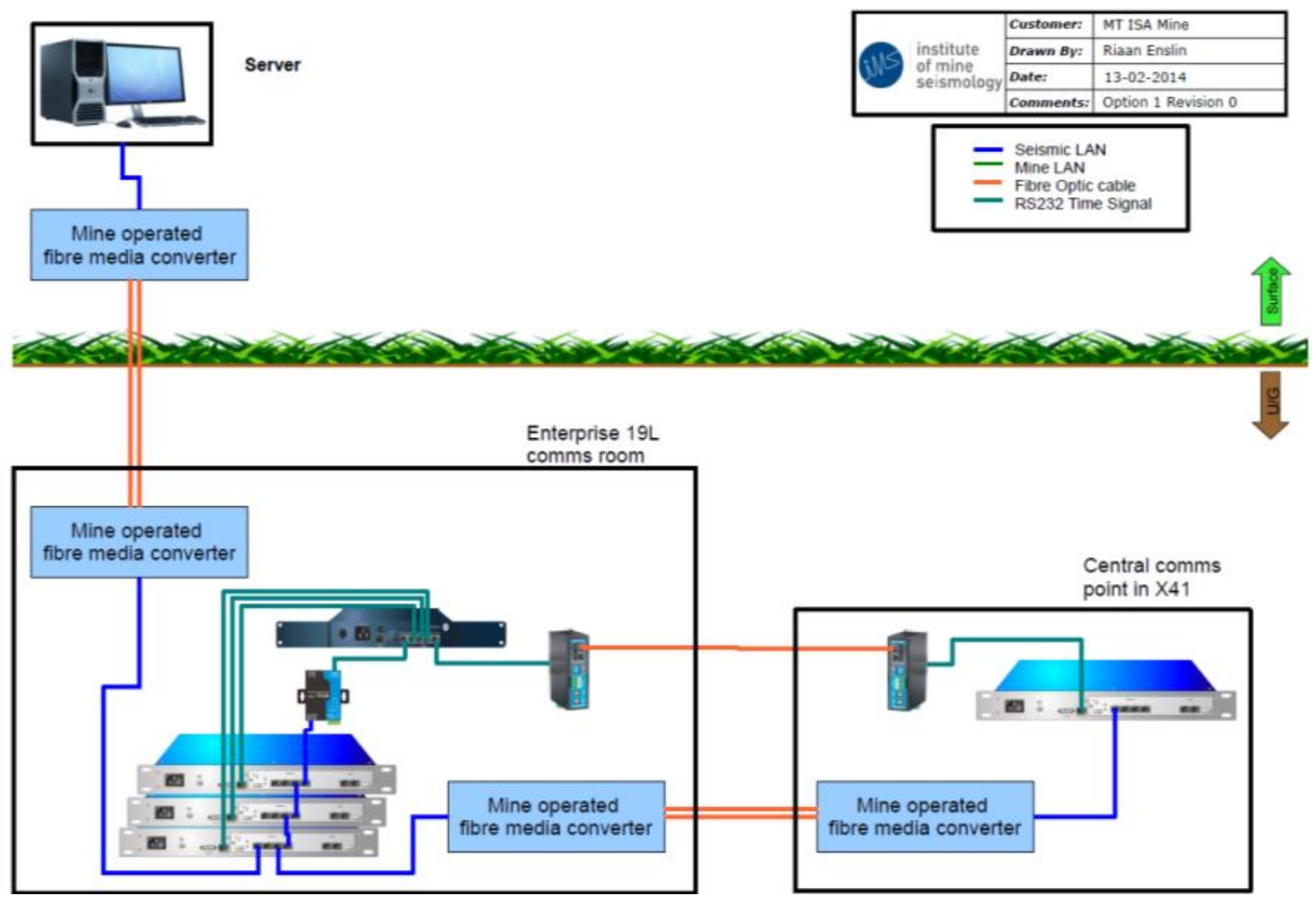

Figure 20 Seismic extension to X41 shaft 


\subsection{Blast vibration modelling}

Mount Isa Mines has a blast vibration prediction model which is routinely used to manage surface blast vibrations were exceedance of regulatory limits has been identified as a risk to the operation. Modelling allows the engineers to adjust timings and maximum instantaneous charge weights to maintain PPV to within tolerable limits. Currently, the maximum allowable PPV for $X 41$ shaft is $50 \mathrm{~mm} / \mathrm{s}^{-1}$ and this will be reviewed and, if necessary, revised based on observations made during initial firings (Table 2).

Table 2 Tolerable PPV limits

\begin{tabular}{|c|c|c|}
\hline Source & Structure & $\begin{array}{l}\text { Maximum PPV } \\
(\mathrm{mm} / \mathrm{s})\end{array}$ \\
\hline \multirow{2}{*}{$\begin{array}{l}\text { AS } 2187.2 \\
\text { (Standards } \\
\text { Australia 1993) }\end{array}$} & $\begin{array}{l}\text { Houses, low-rise residential and non-steel } \\
\text { commercial }\end{array}$ & 10 \\
\hline & $\begin{array}{l}\text { Commercial and industrial of reinforced } \\
\text { concrete or steel }\end{array}$ & 25 \\
\hline \multirow{4}{*}{$\begin{array}{l}\text { BS } 7385.2 \\
\text { (British Standard } \\
\text { Institution 1993) }\end{array}$} & $\begin{array}{l}\text { Reinforced or framed structures } \\
\text { (industrial/heavy commercial) }\end{array}$ & $50 @ 4 \mathrm{~Hz}$ \\
\hline & \multirow{3}{*}{$\begin{array}{l}\text { Unreinforced or light framed structures } \\
\text { (residential/light commercial) }\end{array}$} & $15 @ 4 \mathrm{~Hz}$ to \\
\hline & & $20 @ 15 \mathrm{~Hz}$ to \\
\hline & & $50 @ 40 \mathrm{~Hz}$ \\
\hline $\begin{array}{l}\text { Nicholls et al. } \\
\text { (1971) }\end{array}$ & Residential structures (USBM) & 51 \\
\hline \multirow[t]{5}{*}{ Siskind (2000) } & Commercial and engineered structures & 102 \\
\hline & Vibrations tolerance for buried utilities & 127 \\
\hline & $\begin{array}{l}\text { Lowest vibration for masonry foundation } \\
\text { cracking }\end{array}$ & 127 \\
\hline & Threshold for cracking of mass concrete & 254 \\
\hline & Damage threshold for underground works & 305 \\
\hline \multirow{3}{*}{$\begin{array}{l}\text { Morhard et al. } \\
\text { (1987) }\end{array}$} & Intact rock - minor tensile slabbing & 254 \\
\hline & $\begin{array}{l}\text { Intact rock - strong tensile and some radical } \\
\text { cracking }\end{array}$ & 635 \\
\hline & $\begin{array}{l}\text { Intact rock - complete break-up of rock } \\
\text { masses }\end{array}$ & 2,540 \\
\hline \multirow[t]{4}{*}{ Calder (1977) } & Houses (plaster cracking) & 51 \\
\hline & Concrete blocks in new home & 203 \\
\hline & $\begin{array}{l}\text { Mechanical equipment, pumps, compressors } \\
\text { (shafts misaligned) }\end{array}$ & 1,016 \\
\hline & Prefabricated metal building on concrete slab & 1,524 \\
\hline
\end{tabular}




\subsection{Shaft inspections}

Rock mechanics personnel conduct monthly shaft inspections of X41 in addition to the weekly shaft inspections conducted by shaft maintenance personnel. The inspections by the rock mechanics are logged and all recommendations and work following from these inspections are recorded.

Shaft inspections have proved to be an effective control when mining activities have taken place in close proximity to shafts at Mount Isa Mines.

\subsection{Shaft closure and reopening}

As part of normal mining activities, when required, shafts are temporarily taken out of service, typically either over firing time or for a period after firing until an inspection can be conducted. This minimises the risks to personnel and to shaft infrastructure when it is believed that mining activities may affect the shaft.

The extraction of the stopes in the X41 shaft pillar will require the shaft to be taken out of service periodically based on instrumentation and inspections. Post firing, rock mechanics engineers will check all shaft monitoring instruments. Then the rock mechanics engineers will conduct a visual inspection with shafts personnel to verify the condition of the shaft. If no significant deterioration is identified then the shaft will be returned to service. If significant damage is observed then remedial actions can be put in place.

\subsection{Shaft maintenance}

X41 shaft has experienced ongoing damage dating back to the late 1980s; this damage has been repaired on an ongoing basis by the shafts maintenance personnel. The work has included at various times the removal of loose portions of the shaft lining, relief of accumulated strains in shaft steelwork, rehabilitation of the lining by pinning and bolting of rocks and slabs, spraying of shotcrete and the application of thin spray-on liner (TSL). The extraction of this stope sequence will result in damage to the shaft at a similar rate and magnitude to the damage previously experienced. The shafts team have proven that they can safely conduct the expected rehabilitation work (refer to Figures 21 and 22).

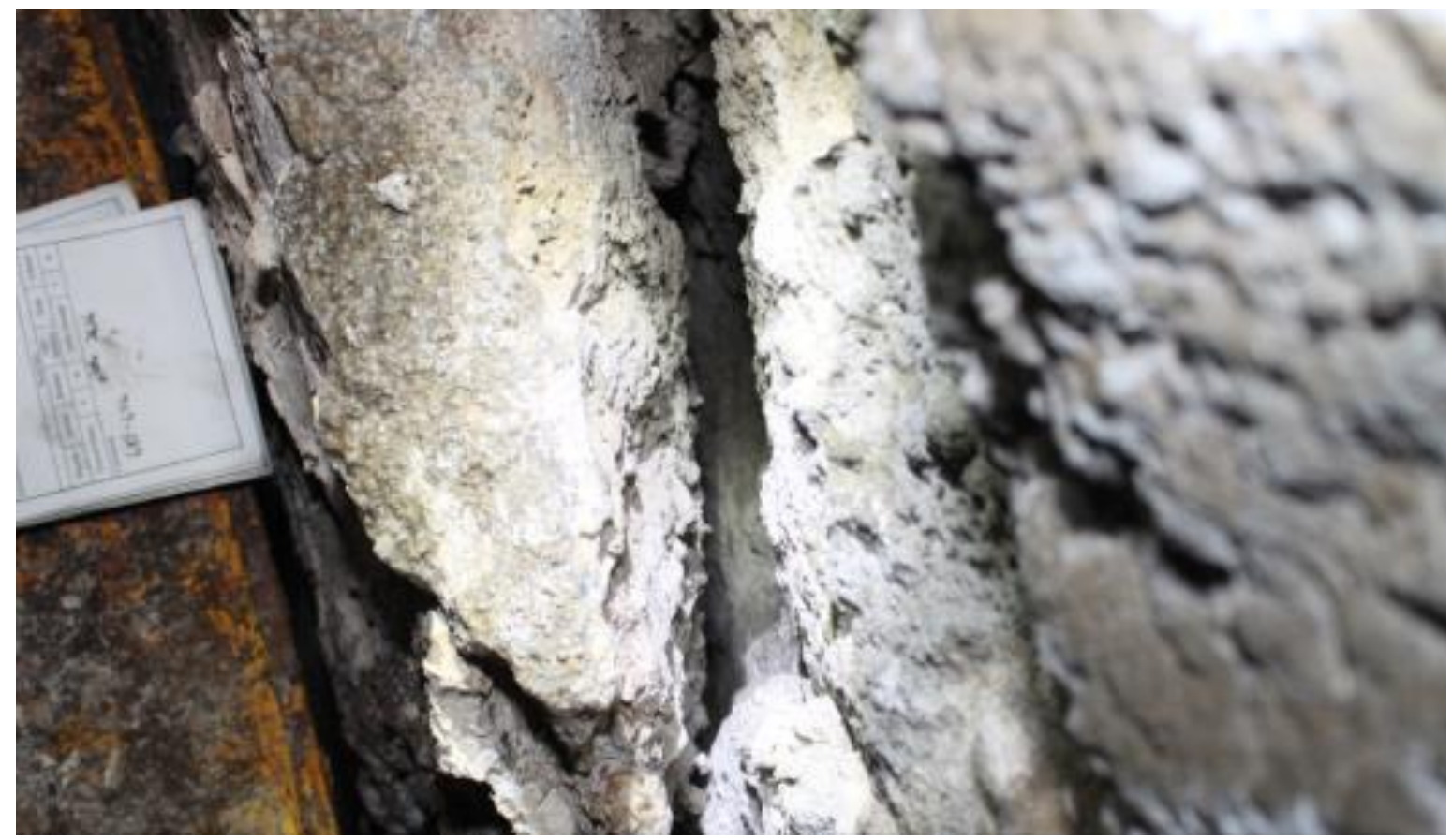

Figure 21 Loose lining prior to removal 


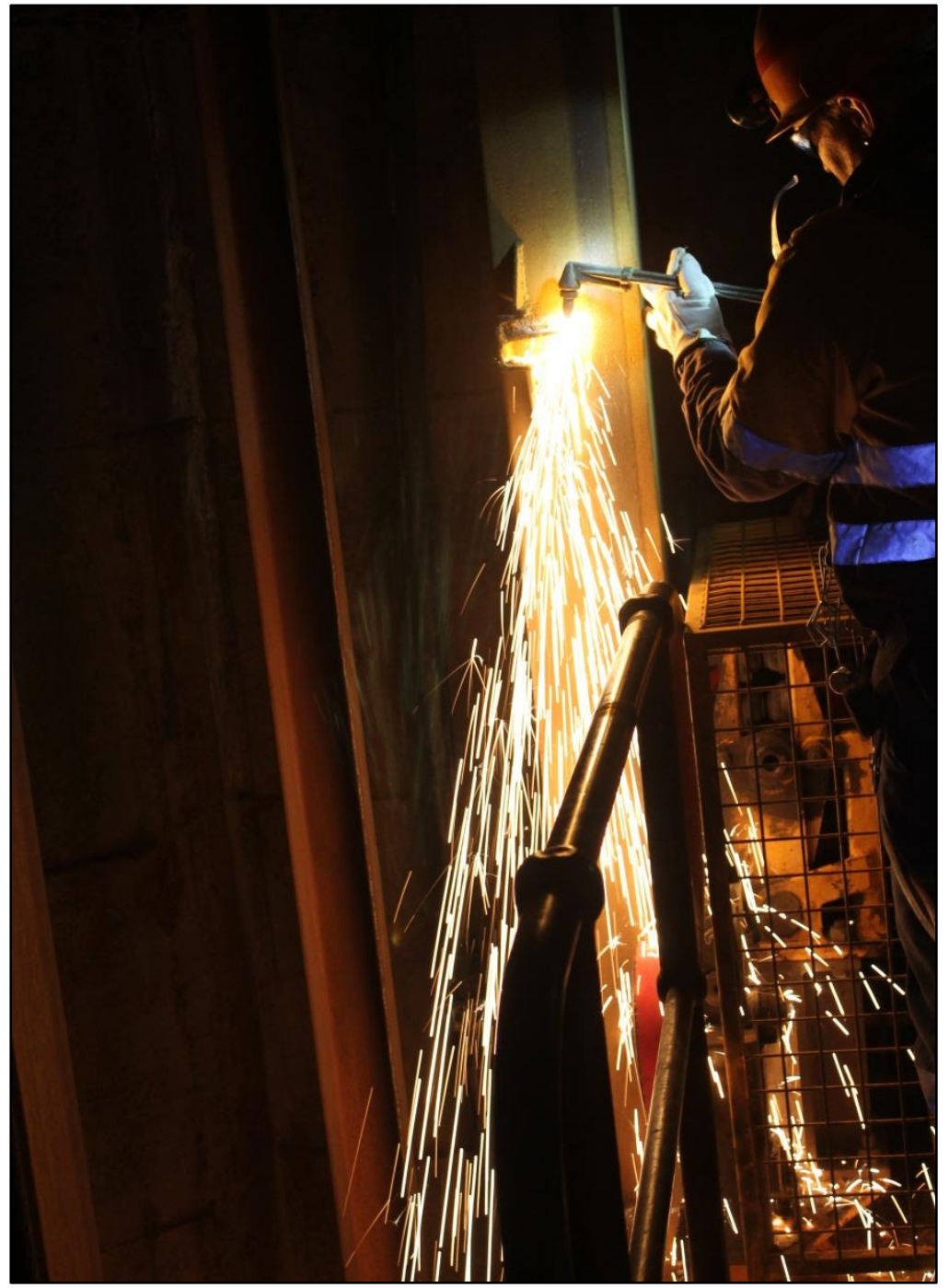

Figure 22 Shaft maintenance

\subsection{Stope redesign and resequencing}

The stopes in this sequence are part of the larger mining plan and will be extracted over the course of the next seven years. The mine schedule is robust and contingency is in place for the redesign and/or resequencing of these stopes based on the performance of the initial production from this area. The timing of the extraction is detailed in Table 3.

Table 3 Stope extraction schedule

\begin{tabular}{ccc}
\hline Stope & Production date & Comment \\
\hline V432 & September 2015 & \\
W429 & January 2018 & \\
V424 & September 2019 & \\
V421 & March 2021 & Beyond current life-of-mine \\
V418 & July 2022 & Beyond current life-of-mine \\
W413 & December 2023 & Beyond current life-of-mine \\
W425 & Not scheduled & Not scheduled \\
\hline
\end{tabular}




\section{$6 \quad$ Future work}

\subsection{Verification against prediction}

The work completed to date has produced predicted deformation rates (Table 4) and has indicated at what point these rates will undergo significant change. The instrumentation and monitoring programs will allow rock mechanics to measure the actual deformation rates. These rates will be monitored closely so that any deviations from the predicted rates will be detected early.

Table 4 Maximum strain and displacement step change (Doolan 2013)

\begin{tabular}{|c|c|c|c|c|c|c|c|c|c|c|c|}
\hline \multirow[b]{2}{*}{$\begin{array}{l}\text { Mining } \\
\text { Step }\end{array}$} & \multirow[b]{2}{*}{ Name } & \multirow[b]{2}{*}{$\begin{array}{l}\text { Stopes } \\
\text { Mined }\end{array}$} & \multirow{2}{*}{$\begin{array}{c}\text { Dist. } \\
\text { Stope } \\
\text { to } \\
\text { shaft } \\
\text { (m) }\end{array}$} & \multicolumn{8}{|c|}{ Change from Previous Mining Step } \\
\hline & & & & $\begin{array}{l}\text { Total } \\
\text { Disp. } \\
\text { (mm) }\end{array}$ & $\begin{array}{l}\text { Elev. } \\
\text { (RL) }\end{array}$ & $\begin{array}{l}\text { Vert. } \\
\text { Disp } \\
(\mathrm{mm})\end{array}$ & $\begin{array}{l}\text { Elev. } \\
\text { (RL) }\end{array}$ & $\begin{array}{l}\text { Horiz. } \\
\text { Disp } \\
(\mathrm{mm})\end{array}$ & $\begin{array}{l}\text { Elev. } \\
\text { (RL) }\end{array}$ & $\begin{array}{l}\text { Micro- } \\
\text { strain }\end{array}$ & Elev. (RL) \\
\hline MS1 & Old Voids & 100 's & 105 & - & - & - & - & - & - & - & - \\
\hline MS2 & S418 & 1 & 193 & -0.6 & 2656 & -0.3 & 2875 & 0.6 & 2680 & 2.9 & 2529 \\
\hline MS3 & U418 & 1 & 119 & 6.5 & 2473 & 6.7 & 2473 & -3.4 & 2557 & 16.0 & 2604 \\
\hline MS4 & V432 & 1 & 115 & -0.8 & 2680 & 0.5 & 2461 & 0.7 & 2660 & $-8,4.4$ & 2620,2549 \\
\hline MS5 & W429 & 1 & 82 & 1.2 & 2521 & 1.4 & 2525 & r0.6 & 2533 & $-15,14$ & 2648,2628 \\
\hline MS6 & V424 & 1 & 93 & 0.3 & 2597 & 0.2 & 2489 & 0.4 & 2596 & 3.7 & 2549 \\
\hline MS7 & V421 & 1 & 79 & -0.3 & 2620 & 0.2 & 2525 & 0.3 & 2592 & 4.3 & 2553 \\
\hline MS8 & V418 & 1 & 60 & -0.8 & 2620 & -0.3 & 2716 & 0.7 & 2620 & 3.0 & 2584 \\
\hline MS9 & W413 & 1 & 56 & -1.0 & 2652 & 0.7 & 2557 & 1.2 & 2652 & 16.0 & 2604 \\
\hline MS10 & W425 & 1 & 42 & 8.3 & 2560 & 7.0 & 2564 & -5.2 & 2560 & $-58,75$ & 2648,2628 \\
\hline MS11 & $\begin{array}{l}1100 \\
\text { Halo } \\
\end{array}$ & $4-6$ & 250 & 5.9 & 2656 & -1.9 & 2895 & -5.4 & 2656 & $-42,40$ & 2903,2626 \\
\hline MS12 & V 406 & 1 & 137 & 3.4 & 2588 & 2.1 & 2525 & -2.6 & 2588 & $-20,21$ & 2903,2656 \\
\hline MS13 & V 402 & 1 & 162 & 0.3 & 2740 & -0.2 & 2732 & -0.2 & 2636 & 2.5 & 2620 \\
\hline MS14 & Panel & 1 & 213 & 0.2 & 2740 & 0.1 & 2465 & -0.1 & 2541 & -0.5 & 2620 \\
\hline MS15 & EOM & $50+$ & 218 & 10.0 & 2429 & 6.9 & 2429 & -7.2 & 2429 & -26.8 & 2903 \\
\hline
\end{tabular}

\subsection{Calibration of current models}

The majority of the instrumentation is in place and is collecting baseline data as shown in Figures 23, 24, 25 and 26. The baseline data in conjunction with the data obtained during initial mining will allow for the calibration of the numerical models used to predict deformation. Based on the calibrated models, mining limits will be adjusted to ensure the optimum safe extraction of the X41 shaft pillar. 


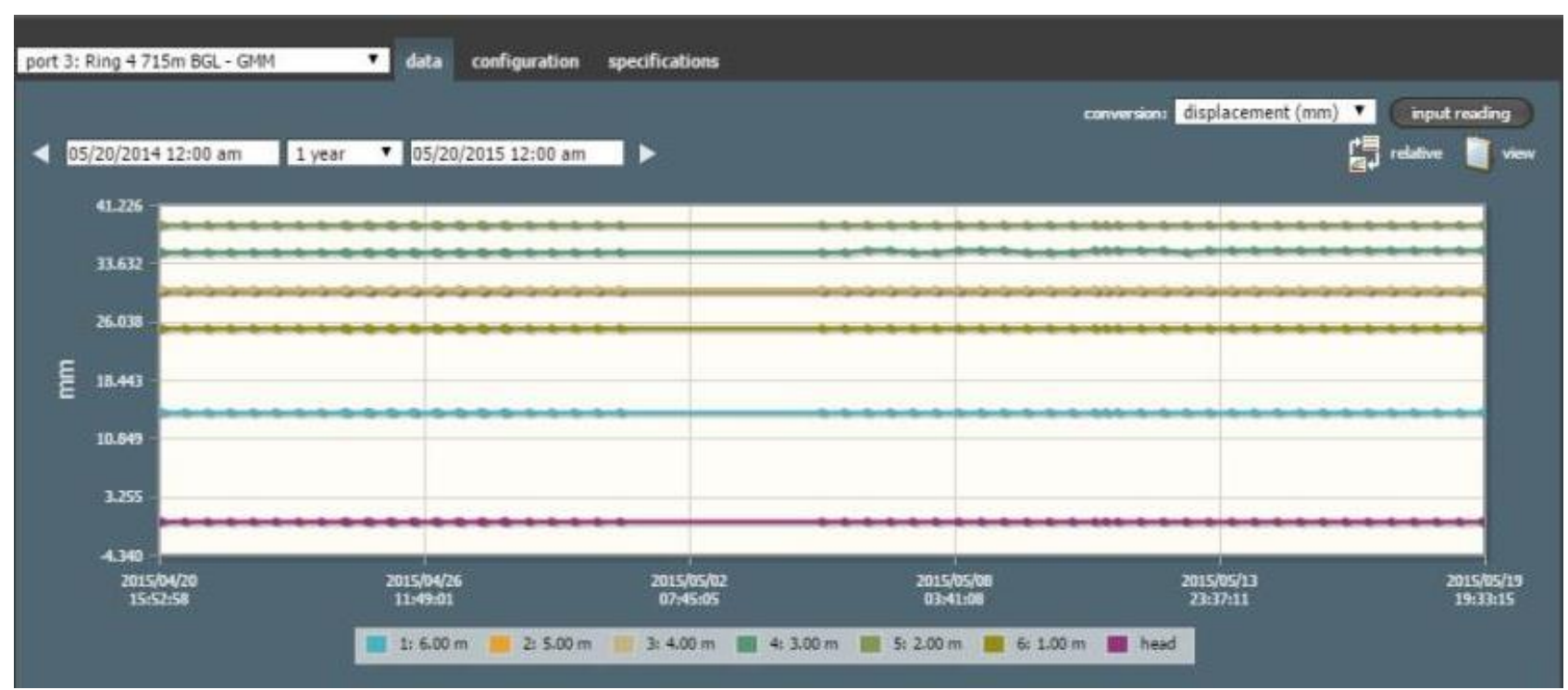

Figure 23 GMM baseline data

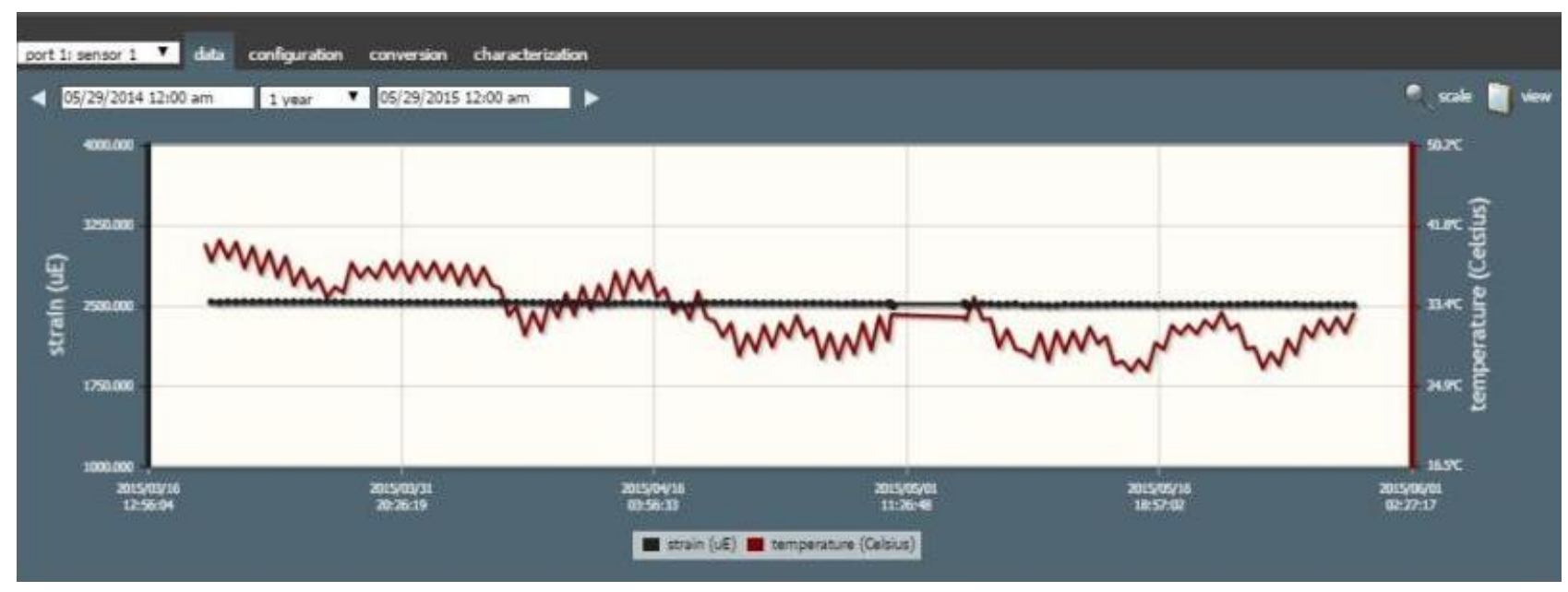

Figure 24 Strain gauge baseline data

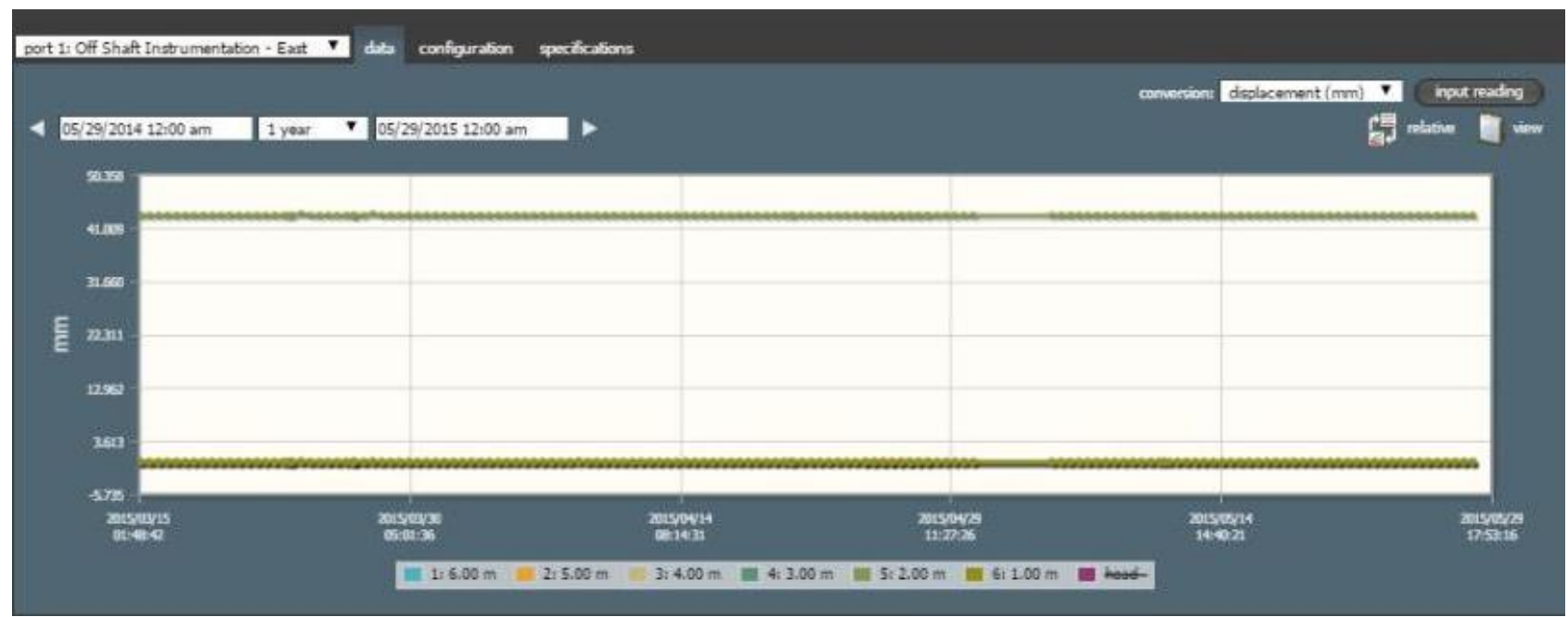

Figure 25 Bar extensometer baseline data 


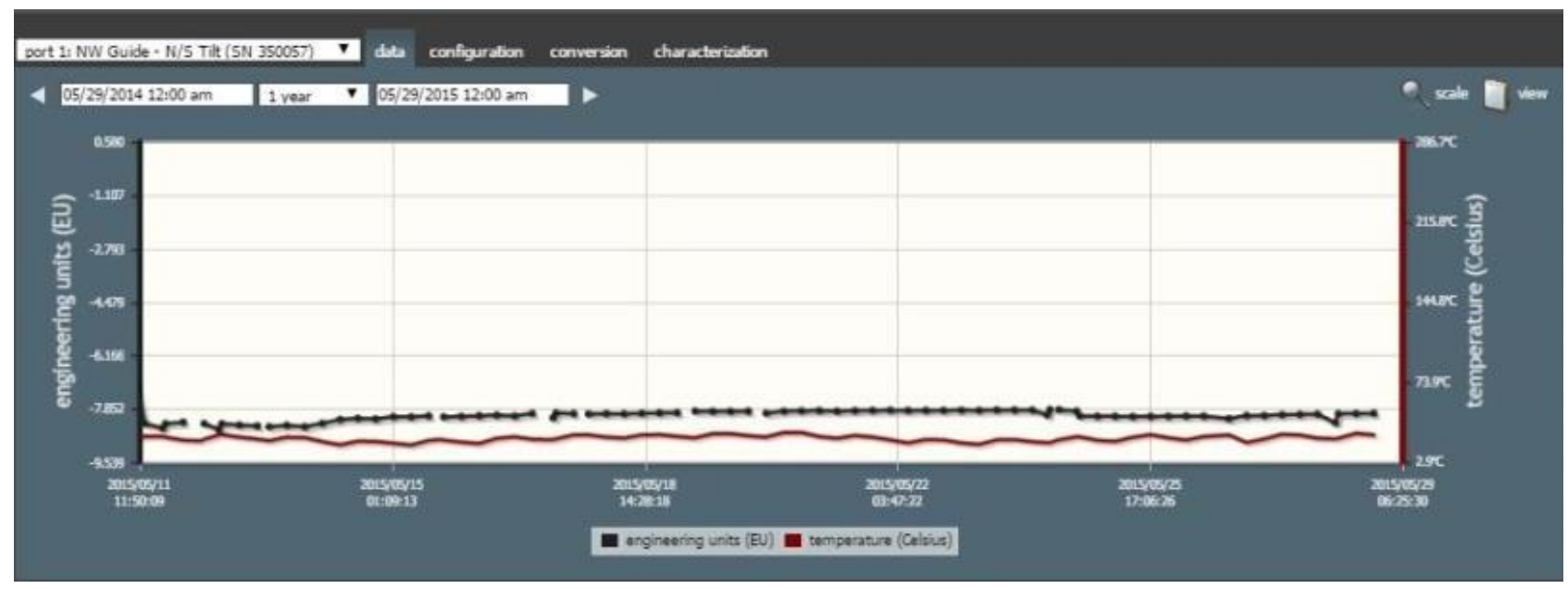

Figure 26 Tiltmeter baseline data

\section{$7 \quad$ Acknowledgement}

I would like to thank Mount Isa Mines management for allowing me to prepare and present this paper. I thank the rock mechanics both past and current whose hard work has made this paper possible.

\section{References}

British Standard Institution 1993, British Standard BS 7385: Evaluation and Measurement for Vibration in Buildings - Part 2: Guide to Damage levels from Groundborne Vibration, BSI, London.

Bruneau, G 2000, 'The influence of faulting on the structural integrity of the X41 shaft, copper mine, Mount Isa, Australia' Master of Science thesis, Laval University.

Bruneau, G, Hudyma, MR, Hadjigeorgiou, J \& Potvin, Y 2003a, 'Influence of faulting on a mine shaft-a case study: part II numerical modelling', International Journal of Rock Mechanics and Mining Sciences, vol. 40, no. 1, pp. 113-125.

Bruneau, G, Tyler, DB, Hadjigeorgiou, J \& Potvin, Y 2003b, 'Influence of faulting on a mine shaft-a case study: part I-background and instrumentation', International Journal of Rock Mechanics and Mining Sciences, vol. 40, pp. 95-111.

Calder, PN 1977, 'Perimeter blasting', Pit slope manual, Canadian Center for Mineral and Energy Technology, Vancouver, BC, no. 77-14, pp. 60-82.

Doolan, J 2013, Shaft pillar assessment X41 shaft for Glencore Xstrata, report, prepared for Mining One Consultants, Melbourne.

Hills, P 2014, Mount Isa copper operations X41 shaft recommendations for instrumentation and monitoring, report, prepared for pitt\&sherry, Launceston.

Morhard, RC 1987, Explosives and rock blasting, Blasters Tool \& Supply Co, Lawrenceburg, KY.

Nicholls, HR, Johnson, CF \& Duvall, WI 1971, 'Blasting vibrations and their effects on structures', Bulletin of the United States Department of the Interior Bureau of Mines, USBM, Washington DC, no. 656.

Siskind, DE 2000, Vibrations from blasting, International Society of Explosive Engineers, Cleveland, OH.

Sloane, L 2005a, Is 20050622 X41 shaft instrumentation status, internal report, prepared for Mount Isa Mines, Mount Isa.

Sloane, L 2005b, Is 20050815_X41 shaft instrumentation requirements, internal report, prepared for Mount Isa Mines, Mount Isa.

Standards Australia 1993, Australian Standard AS2817.2: Explosives - Storage, Transport and Use, Part 2: Use of Explosives, Standards Australia, Sydney. 